\title{
Grammatical Interference from English into Indonesian Language Made by English Native Speakers in Salatiga
}

\author{
Ratih Asti Supriyanto \\ English Department of Educational Faculty \\ State Islamic Studies Institute (STAIN) Salatiga \\ Jl. Tentara Pelajar No. 02 Salatiga, Central Java, Indonesia \\ nature.asti@gmail.com
}

\begin{abstract}
This research was carried out the syntactic interference from English to Indonesian language made by English native speakers in Salatiga. This study was also intended to find out morphological interference from English to Indonesian language made by English native speakers in Salatiga. The research method used was interviewing, recording and transcribing. This method was applied by interviewing English native speakers, then the writer recorded and transcribed to find out the interference that they made. After the data had been collected and analyzed, the writer finds several sub-classifications in syntactic interference as the following: (1) sentence; (2) phrase; (3) diction; and syntactic interference are dominated by phrase, because the phrase construction of English and Indonesian language is different. The construction phrase of Indonesian language is head word + modifier, but in English head word is put after the modifier. Meanwhile for morphological interference is dominated by applying the base form in using the verbs in sentence. The construction of verb in English does not need the inflectional morphology to make the sentence clear as the Indonesian language. The speakers have a tendency to use the base form to show the verb in Indonesian sentence.
\end{abstract}

Keywords: Interference, Syntactic interference, Morphological interference. 


\begin{abstract}
Abstrak
Penelitian ini menyajikan interferensi sintaksis dari bahasa Inggris ke bahasa Indonesia yang dibuat oleh penutur asli bahasa Inggris di Salatiga. Penelitian ini juga dimaksudkan untuk menemukan interferensi morfologi dari bahasa Inggris ke bahasa Indonesia yang dibuat oleh penutur asli bahasa Inggris di Salatiga. Metode yang digunakan adalah wawancara, rekaman dan transkrip. Metode ini diterapkan dengan mewawancarai penutur asli bahasa Inggris, kemudian penulis merekam dan mentranskrip hasil wawancara untuk mengetahui interferensi yang mereka buat. Setelah data dikumpulkan dan dianalisis, penulis menemukan beberapa sub - klasifikasi interferensi sintaksis sebagai berikut : (1) kalimat, (2) frase, (3) diksi, dan gangguan sintaksis didominasi oleh frase, karena konstruksi frase bahasa Inggris dan bahasa Indonesia berbeda. Susunan frase dalam bahasa Indonesia adalah kata + modifikator, tapi dalam bahasa Inggris kata diletakkan setelah modifikator. Sementara itu interferensi morfologi didominasi dengan menerapkan bentuk dasar dalam menggunakan kata kerja pada kalimat. Dalam bahasa Inggris konstruksi kata kerja tidak memerlukan infleksi morfologi untuk membuat kalimatnya jelas sebagaimana yang berlaku dalam bahasa Indonesia. Para pembicara memiliki kecenderungan untuk menggunakan bentuk dasar pada kata kerja yang mereka gunakan dalam kalimat bahasa Indonesia.
\end{abstract}

Kata Kunci : Interferensi, Interferensi sintaksis, Interferensi morfologi

\title{
Introduction
}

Communication is the requirement of life. As social creatures, people need it, and language is perfect tool to communicate. Recently learning language, especially more than one language is important for people in the world, because it can be the bridge to communicate with others in different places, even different countries. In fact, there are some constraints to do it, people who learn different language will find difficulties to learn the grammar, vocabularies, even phonetic aspect in that language. As the result, they will mix the same aspects from their 
mother tongue to language that they learn. In linguistics, this phenomenon is called interference.

The first scholar who introduces interference is Weinreich in 1953. He used interference to clarify the systemic change in language because of contiguity between that language and the other language that made by bilingual speaker (Chaer and Agustina, 2004:120).

Meanwhile according to Robert Lado, bilingualism is individual capability to use two languages equally well or almost equal technically referred to the knowledge of two languages whatever its degree (Chaer and Agustina, 2004:86). Almost bilingual people make interference in the beginning when they speak in their target language. For example, Indonesian who learns English, they will make interference in their writing or their speaking skill in the target language, in this case English.

According to Pudiyono's research (2012:6), the structural of Indonesian language can be influenced in practice by Indonesian students; it's like the following sentence: Dia sangat mencintai adiknya. With such grammatical pattern as the example, an Indonesian learning English could capably express the idea just like in Indonesian pattern as the following: She very loves her brother. Definitely, this utterance is not grammatically acceptable in English. The correct grammatical rule is the word very cannot be used to explain adverb such very loves. Very in English is used to modify an adjective. Therefore, the morpheme very is linked directly before an adjective, for instance: very busy, very beautiful, very angry, very important, very much, very little, very handsome, etc. In short, the word very cannot stand alone. On the contrary, the word, which can be used to modify an English verb, is very much. 
On the other hand, English native speakers who learn Indonesian language could also experience language interference, not only Indonesian who learns English. When the writer met English native speakers, the writer heard that consonant " $t$ " will be "c" when they spoke in Indonesian language. For example, the word tahu/tempe will be cahu/cempe, it is called phonic interference. Besides, language interference could also appear in morphological and syntactical areas which could be included in grammatical interference. Considering the situation above, the writer curious to find and identify kinds of syntactical and morphological interference from English to Indonesian language made by English native speakers in Salatiga.

\section{Interference}

The first scholar who used interference is Weinreich in 1953, he formulated interference to clarify the systemic change in language because of contiguity between that language and the other language that are made by bilingual speaker (Chaer and Agustina, 2004:120). Then, more than a decade ago, Fishman in 1971 decried the extensive and arbitrary employment of the term "interference" by many linguists in reference to any number of bilingual phenomena. (Poplack, 1983:11)

Instead of making the usual field work assumption that the underlying structures of the varieties encountered in bilingual speech communities were unknown, linguists have usually assumed that they were known, but basically nothing more than X "Interfering" with $\mathrm{Y}$ and vice versa. As a result they frequently failed to familiarize themselves with the communities and speakers from which they obtained their corpuses of speech. 
Alwasilah (1985:131) explored the notion of interference based on Hartman and Stonk that interference is a mistake caused by the propensity of habitually used pronunciation (speech) of a language to another language pronunciation unit includes sounds, grammar, and vocabulary. Meanwhile, Valdman's opinion in 1966 as cited by Hayi, et.al (1985) mentions that interference is an obstacle because of speaker habits on mother language (first language) in the study of language acquisition (second language). Consequently, there will be transfer of negative elements from the mother language into the target language.

Suhendra Yusuf (1994:67) stated that the main factors of interference are the differences between the source language and the target language. The differences are not only in structure but also the variety of vocabularies. Another notion advanced by Jendra (1991:187), he declared that the interference is the infiltration system of a language into another language. Interference arises from implementing unit system of sounds (phonemes) by bilingual in a first language into a second language sound system, which causes chaos or irregularities at the phonemic system of the recipient language. Interference is a common symptom in sociolinguistic that occurs as a result of language contact, the use of two or more languages in the speech multilingual community. This case is an issue that attracted attention for linguists.

\section{Syntactic interference}

Interference occurs when the syntactic structure of a language is absorbed by the other language (Suwito, 1983:56). Interference can be seen in the use of syntactic fragments of words, phrases and clauses in 
sentences (Chaer and Agustina, 2004:124). For example, English and Indonesian phrases.

English

Santika Hotel

Salatiga Kota
Indonesian

Hotel Santika

Kota Salatiga

The other example can be seen in the sentences, Dina reads the poetry with beautiful. In English this sentence is not exist, because the right form is Dina reads the poetry beautifully. From this case, the interference can be proved, cause the sentence "Dina reads the poetry with beautiful" is the translation from the sentence "Dina membaca puisi dengan indah"

\section{Morphological interference}

According to Suwito (1983:55) morphological interference occur if the formation of word in a language absorbs the affixes from other languages. The affix of a language used to spell a word in another language, while affixes consist of prefix, suffix, inserts, as well as combinations of affixes. For examples, morphological interference from Javanese into Indonesian language. In words ketrabak/ kebawa and kebagusan/ keasinan

$\begin{array}{lll}\text { Javanese } & \text { Indonesian } & \text { English } \\ \text { Ke-tabrak } & \text { Tertabrak } & \text { accidentally crashed into } \\ \text { Ke-bawa } & \text { Terbawa } & \text { taken along (accidentally) } \\ \text { Ke-asin-an } & \text { Terlalu asin } & \text { saltiness } \\ \text { Ke-bagus-an } & \text { Terlalu bagus too good }\end{array}$

\section{Research method}

The type of this research was qualitative research. The specific thing that observed and analyzed was the utterances comprise of words, 
phrases, clauses, and sentences made by English native speakers in Salatiga.

The writer took the subjects of research to get the data through purposive sampling technique. According to Arikunto (2006: 183) Purposive sampling is a technique of sampling based on some consideration. There are ten subjects in this research. They are nine Americans and one Dutchman who speak English since they were child. Their names are Peter Greenwald as a pilot; Ashley Greenwald as housewife; Peter Anderson Neal as a Pilot; Joy Marcie Neal as housewife; Melissa Jean Kroneman as housewife; Klaash Christian Kroneman as a pilot; Karren Fosdahl and Tabitha Julia Kidwell as a lecturer; Shad Chris Deal as a constructor; and Sarah Christine Shad as a housewife. The writer did the interview, then recording and transcribing to get the data. After data had been collected, the writer analyzed the data based on the syntactical and morphological interference in order to find out their classification.

\section{Discussion}

Syntactic interference

Sentence

Suhendra Yusuf (1994:67) states that the main factors of interference are the differences between the source language and the target language. The differences are not only in structure but also in the variety of vocabularies. Thus, the structure of the target language always influences the interference made by bilinguals. Meanwhile, structure of English and Indonesian language in the sentence has similarities:

1) Kemudian saya bekerja sebagai instruktur pilot untuk pilot, baru murid ya. 
(Then, I worked as a pilot instructor for a pilot, the new student) It is $\mathrm{S}+\mathrm{P}+\mathrm{O}$ which make foreigners easier to learn Indonesian language. Hence, there is limited interference in structure of sentence.

Kemudian saya bekerja sebagai insruktur pilot untuk pilot, baru murid ya from the sentence, then, I worked as a pilot instructor for a pilot, the new student. The structure is right. There are; I/ saya as a subject, worked / bekerja as a predicate, as a pilot instructor / sebagai instruktur pilot as an object, and complement is for a pilot, the new student / untuk pilot,baru murid. The sentence structure is complete, subject, predicate, object, and the complement existed in the sentence above,but for the level of phrase, interference exists in the phrase baru murid. The phrase interference will be discussed in the next sub topic.

Phrase

There is a tendency, English native speakers made syntactic interference in the phrase construction and the diction in the sentence. Phrase interference occured due to the construction of the phrase in the English language interference into Indonesian used by English native speakers in Salatiga. There is the difference between English phrase and Indonesian phrase, in English construction, phrase consist of modifier + head word for example the new + student, while the Indonesian structure is head word + modifier for example murid + baru (student + new). It seems that the difference cause phrase interference from English to Indonesian language. As data below;

2) Kemudian Saya bekerja sebagai insruktur pilot untuk pilot, baru murid ya. (Then, I worked as a pilot instructor for a pilot, the new student.)

The pattern of baru murid is modifier + head word. It is clear that the speaker used English phrase construction. When he spoke in Indonesian, the correct pattern is head word + modifier or murid baru. It should be, Kemudian saya bekerja sebagai instruktur 
untuk pilot, murid baru ya. (Then, I worked as a pilot instructor for a pilot, the new student.)

3) Menjelaskan bagaimana kami rencana membantu orang yang hidup disini.(Explain how our plan to help the people who live here)

There is interference from English pattern in Kami rencana (our plan). The pattern of the noun phrase is modifier (possessive pronoun) + head word (noun). It is English pattern compare to Indonesian phrase head word + modifier. The phrase should be rencana kami. Menjelaskan bagaimana rencana kami membantu orang yang hidup disini. (Explain how our plan to help the people who live here)

4) Oh food, kesukaan makan, banyak kata panjang ya ?(Oh food, favorite food, a lot of long words huh? )

Actually in the phrase kesukaan makan (favorite food), the interference is not only in the structure, but also in the morphological aspect that will be discussed in the sub chapter two number 23. As the previous data, there is English interference in kesukaan makan (favorite food). Using English pattern modifier + head word. Conversely, Indonesian phrase construction is head word + modifier, so the sentence should be, Oh food, (makanan) kesukaan, banyak kata panjang ya? (Oh food, favorite food, a lot of long words huh? )

5) Em..Lincoln kota.(Em.. Lincoln city)

Lincoln kota is the English phrase modifier + head word, so it is phrase interference. It will be correct if the speaker use Indonesian pattern head word + modifier. So the phrase should be, Em..kota Lincoln.(Em.. Lincoln city)

6) Saya hanya anak di orang tua. (I am the only child of parents)

As the previous data, the phrase hanya anak (the only child) has been interfered by English pattern, modifier + head word. The correct pattern is head word + modifier or anak hanya (the only child). In addition, hanya anak (the only child) has also interference in diction that will be discussed in the sub chapter $1 \mathrm{~b}$, so the right sentence should be, saya anak (tunggal) di orang tua. (I am the only child of parents)

The other interference in phrase is dating, while there are some ways to inform the date for English native speakers depend on the orientation, British or American, 
British: Day-Month-Year

the twenty sixth of July, 2013

$26^{\text {th }}$ July 2013

26 July 2013

$26 / 7 / 2013$

$26 / 7 / 13$

26/07/13
American: Month-Day-Year

July the twenty sixth, 2013

July $26^{\text {th }}, 2013$

July 26, 2013

$7 / 26 / 2013$

$7 / 26 / 13$

$07 / 26 / 2015$

Because the subjects of this research are American, so they commonly used the second type in dating. Meanwhile, it is common in Indonesian language to use the first type / British type. The interferences are caused by American speakers who use the second type in Indonesian language. As the data below;

7) Sekarang baru tiba sama dengan istri Saya, Januari 12013.

(Recently arrived, same with my wife, January $1^{\text {st }} 2013$ )

It should be, Sekarang baru tiba sama dengan istri saya, 1 Januari 2013. (Recently arrived, same with my wife, January $1^{\text {st }}$ 2013)

Mostly, except phrase construction and dating, the interference was also happened in the preposition. Most of data stated that speakers had incorrect translation for English preposition to Indonesian preposition. They considered that it has same meaning. For examples are $d i$ - and $k e-, d i$ - is the preposition of place relation (at), but $k e$ - is refers to direction of the place (that will go). (Moeliono, 1997:230).

In the sentences below, the words came here is translated by datang di sini. It is incorrect translation, because came / datang explains the place that will be, as the data below;

8) Waktu kami datang di sini. (When we came here) It should be,Waktu kami datang ke sini. .(When we came here)

9) Saya sebelum datang di sini Saya murid univesitas. (Before I came here, I am a university student)

It should be, Saya sebelum datang ke sini, saya murid universitas. (Before I came here, I am a university student) 
10) Di tempat jauh sekali, jadi saya bisa pergi ke sana dengan rencana kedutaan. (In the far place, so I can go there with the embassy schedule)

As like the previous data, di tempat jauh sekali .(In the far place) is followed by go, and go explains the place that will be. So the correct translation is ke tempat jauh sekali.(in the far place)

The sentence should be, Ke tempat (yang) jauh sekali,jadi saya bisa pergi ke sana dengan rencana kedutaan. (In the far place, so I can go there with the embassy schedule)

11) Tetapi saya naik pesawat, eh untuk organisasi dan em di satu tahun. (But I get on the plane for organization in one year)

Different from the previous data, in this sentence, the speaker explains how long he will work in his organization. In Indonesian language, the preposition used selama as a sign of the relation of time era. And it should be,Tetapi saya naik pesawat, eh untuk organisasi dan em selama satu tahun. (But I get on the plane for organization in one year )

The next preposition is kepada to replace for in English language.

In Indonesian language, kepada is the preposition that indicates the relation of direction, conversely in sentences below the speaker has tendency to indicate the relation of allocation. So the appropriate word is untuk, bagi, guna, or buat to replace for in English.

12) Saya membaca admission application kepada orang-orang. (I read admission application for people.)

It should be, Saya membaca admission application untuk orangorang. (I read admission application for people.)

13) Ya Ramayana atau Ada Baru untuk popok diaper popok ya kepada anak saya ya. (Yes Ramayana or Adabaru for diapers, diapers for my child)

In this context, it should be, Ya Ramayana atau Ada baru untuk popok diaper popok ya buat anak Saya ya. (Yes Ramayana or Adabaru for diapers, diapers for my child)

14) Saya pergi ke Kalimantan sudahsaya belajar Indonesian Indonesia untuk satu tahun. (I go to Kalimantan after I studied Indonesian language for a year ) 
The interference in sentence above is for that was translated by untuk, but has a meaning selama as a sign of the relation of time era.

Actually, in the sentence above has interference in morphological aspect too that will be discussed in the sub chapter two. In this context, for has a meaning selama and it should be, Saya pergi ke Kalimantan (sesudah)saya belajar Indonesian Indonesia selama satu tahun. (I go to Kalimantan after I studied Indonesian language for a year )

The interference in the sentence below is incorrect translation for the word by. Whereas, by or oleh is preposition that indicates the object relation, while the speaker explained the preposition of manner and the appropriate word is dengan.

15) Saya belajar oleh internet aja. (I learned by internet)

In the context of sentence above, oleh internet is the preposition of manner. It should be, Saya belajar dengan (menggunakan) internet aja. (I learned by internet)

\section{Diction}

In the level of sentence, the writer found the interference in the relative clause as the data below;

16) Saya punya teman, teman di pasar siapa punya warung atau toko. (I have a friend, a friend in the market who has a stall or store) In English sentence, relative pronoun used who to explain the object a friend in the sentence. The relative pronoun who cannot be interpreted directly in Indonesian language siapa. who or siapa in Indonesian language that used in the interrogative sentence, and the speaker supposed to use yangto translate the relative pronoun who, Kamus Besar Bahasa Indonesia (2007), the word yang used to clarify the previous word in the sentence as the 
function of relative pronoun above. Hence, it should be, saya punya teman, teman di pasar yang punya warung atau toko. (I have a friend, a friend in the market who has a stall or store)

Another interference in sentence is diction which was influenced by English language as a native language of the subjects, As the data;

17) Saya mohon maaf suami saya tidak bisa dipanggil. (I am sorry, my husband cannot be called )

Dipanggil in Indonesian language means ask for coming, but in the context of sentence above is contact via phone. And call itself in the dictionary has some meanings, there are memanggil, menyebut, mengadakan, menelepon and etc. The appropriate diction for the sentence should be ditelepon or dihubungi. So the sentence should be, saya mohon maaf suami saya tidak bisa dihubungi. (I am sorry, my husband cannot be called )

18) Waktu kami selesai di IMLAC kami pergi ke Banda Aceh untuk suami Saya.(When we finished in IMLAC we will go to Banda Aceh for my husband)

In this context, when is time of chronological. Meanwhile in the dictionary when has some meaning, there are kapan, ketika, waktu, and etc. The appropriate diction for the sentence is sesudah/ setelah because the context is chronological time. It should be, Setelah kami selesai di IMLAC kami pergi ke Banda Aceh untuk suami saya. (When we finished in IMLAC we will goto Banda Aceh for my husband)

19) Tidak makan orang Indonesia.(It is not Indonesian food)

Tidak in the sentence above means abjuration. The sentence will mean, if the speaker use the appropriate diction bukan in this context, because bukan in Kamus Besar Bahasa Indonesia (2007) means abjuration. In addition, the sentence above has other interference in morphological aspect that will clarify in the next 
discussion. So the sentence should be, Bukan (makanan) orang Indonesia. (It is not Indonesian food)

\section{Morphological interference}

Actually, morphological process between Indonesian and English language is absolutely different. Morphological aspect is divided into two kinds, there are inflection and derivation. Verhaar (1983:66) explains that inflectional morphology is the alteration of morpheme which defends the lexical identity. In English, inflectional morphology altered by suffixes, examples cat $+s=$ cats (would be plural form of nouns), play $+e d=$ played (would be the past form of regular verbs). Meanwhile, in Indonesian language, inflectional morphology is often in the verb by adding prefixes and konfixes (the combination of prefixes and suffixes). As the example, by adding prefix me + tulis $($ verb $)=$ menulis $($ verb $) / d i+$ tulis $=$ ditulis, by adding konfix me + tulis + kan = menuliskan(verb).

Later, derivational morphology according to (Verhaar, 1983:65) the alteration of morpheme that produces the word with the different lexical identity. English and Indonesian language have the same way to derivate the word, adding the prefix, suffix, and the combination of them. In English as examples, $b i+\operatorname{cycle}($ verb $)=$ bicycle (noun), play $($ verb $)+$ $e r=\operatorname{player}($ noun $)$, and dis + grace $($ noun $)+f u l=$ disgraceful (adjective). Meanwhile, examples in Indonesian language are pe + main $($ verb $)=$ pemain $($ noun $)$, makan $($ verb $)+$ an $=$ makanan $($ noun $)$, and per + main + an = permainan (noun).

The morphological interference in the data below is the using of base form. Speakers used the base form / basic word more regular than the word with affixes. 
20) Saya terbang pasien untuk rumah sakit. (I flew the patient for hospital)

There is no morphological process in the verb flew, just the alteration from fly-flew, without affixes. Whereas, in Indonesian language those sentences above need the morphological process to build the verb as a context. And the speakers translated the word fly directly. Terbang is flying to himself, but in the context of the sentences above mean bring something to fly, so the speakers must add the prefix Me-and suffix-kan (menerbangkan) to make it appropriate with the context above.The morphological interference in this sentence existed because the speaker used English principle to translate the sentence above by using the base form. So the sentences should be; Saya menerbangkan pasien untuk rumah sakit.(I flew the patient for hospital)

21) Kami membawa apa makan dan obat.(We bring food and medicine)

22) Tidak makan orang Indonesia. (It is not Indonesian food)

23) Oh food, kesukaan makan, banyak kata panjang ya?(Oh food, favorite food, a lot of long words huh? )

In sentences above food is the noun without morphological process, but in Indonesian context makanan/food is the derivative word from the word makan. And the speakers used the base form makan to show makanan. The morphological interference in this sentence existed because the speaker used English principle to translate the sentence above by using the base form. So it should be; Kami membawa, apa makanan dan obat; (Bukan) makanan orang Indonesia; Of food, makanan kesukaan, banyak kata panjang ya?. (We bring food and medicine; It is not Indonesian food; Oh food, favorite food, a lot of long words huh?) 
24) Waktu saya lahir anak saya. (When I gave birth to my child.) In sentence above, gave birth is the verb without morphological process. Meanwhile, according to Indonesian language morphological process of building the verb happens in the word lahir. Lahir is out of uterus, but in the sentence above, it means put outside the baby from uterus, so the speaker need affixation Me-kan (melahirkan). The morphological interference in this sentence existed because the speaker used English principle to translate the sentence above by using the base form and it should be; Waktu saya melahirkan anak saya. (When I gave birth to my child.)

25) Saya mundur diri karena gak ada visa. (I back off because I do not have a visa)

In the sentence above, the speaker used the base form mundur to show back off. Mundur diri in Indonesian language is meaningless, the right form is mengundurkan diri, mengundurkan is derivative word from mundur by adding me + kan. It means Retire or back off. The morphological interference in this sentence existed because the speaker used English principle to translate the sentence above by using the base form so it should be; Saya mengundurkan diri karena gak ada visa. (I cancel because I do not have a visa)

26) Saya tidak ucapan betul ya? (I did not say right ya?)

In the sentence above say is the verb, but in Indonesian language ucapan is noun from the base form ucap, there is derivational morphology to alter the word ucapan become mengucapkan (verb). So the speaker must add meng-kan to make it become a verb, so it should be; Saya tidak mengucapkan betul ya? (I did not say right ya?)

27) Saya pergi ke Kalimantan sudah saya belajar Indonesia untuk satu tahun. (I go to Kalimantan after I studied Indonesian language for one year) 
After in the sentence above is not the result of morphological process. In Indonesian language Sudah is finished, but in this context sudah means after, so prefix se- is needed to make the sentence clearly become sesudah (after).

The morphological interference in this sentence existed because the speaker used English principle to translate the sentence above by using the base form. The sentence should be; Saya pergi ke Kalimantan sesudah saya belajar Indonesia untuk satu tahun. (I go to Kalimantan after I studied Indonesian language for one year)

28) Sangat sulit menjelaskan hidup di negara lain kalau orang belum pernah ke sana. (It is hard to describe the life in the other country if someone has not gone there.)

The life in the sentence above means condition and there is no morphological process in that word. Meanwhile, hidup in Indonesian context is the verb, there is derivational process to built the word hidup (verb) become kehidupan (noun) by adding prefix $k e$ - and suffix -an. The morphological interference in this sentence existed because the speaker used English principle to translate the sentence above by using the base form. So it should be; Sangat sulit menjelaskan kehidupan di negara lain kalau orang belum pernah ke sana. (It is hard to describe the life in the other country if someone has not gone there.)

\section{Conclusion}

In the research findings, the writer found some categories of syntactical interference. It consists of three classes, there are in sentence, phrase, and diction. The dominant interference was in the phrase class. 
Interference was found in phrase construction (modifier and head word). The construction phrase of Indonesian language is head word + modifier, but in English head word is put after the modifier. Except the phrase construction, interference was found in the application of preposition in the sentences. Especially when the speakers interpreted here and for.

In addition, the writer also found the morphological interference in application of base form for invention the verb and some nouns. Most of them, the interference in this case happened because the morphological process in English language, especially in the verb construction. In English, verb does not need the inflectional morphology to make the sentence clear as the Indonesian language that needs inflectional morphology in the sentence. As a result, the speakers inclined to use the base form to show the verb in Indonesian sentence.

\section{References}

Alwasilah, A Chaedar. 1985. Beberapa Madhab dan dikotomi Teori Linguistik. Bandung: Angkasa.

Arikunto, Suharsimi. 2006. Prosedur Penelitian Suatu Pendekatan Praktik. Jakarta : PT Rineka Cipta.

Departemen Pendidikan dan Kebudayaan. 2007. Kamus Besar Bahasa Indonesia. Jakarta: Balai Pustaka.

Chaer, Abdul \& Leonie Agustina. 2004. Sosiolingistik: Perkenalan Awal.Jakarta: Rineka Cipta.

Hayi, Abdul, et.al. 1985. Interferensi Gramatika Bahasa Indonesia dalam Bahasa Jawa. Jakarta. Pusat Pembinaan dan Pengembangan Bahasa.

Jendra.I Wayan. 1991. Dasar-Dasar Sosiolinguistik. Denpasar: Ikayana. Moeliono, Anton. 1997. Tata Bahasa Baku Bahasa Indonesia. Jakarta: Balai Pustaka.

Suwito. 1983. Pengantar Awal Sosiolinguistik Teori dan Praktik. Surakarta: Henary Offset. 
Verhaar, J. W. M, 1983. Pengantar Linguistik. Yogyakarta: Gadjah Mada University Press.

Poplack, Shana. 1983. Bilingual Competence: Linguistic Interference or Grammatical Integrity? . New York: University of New York.

Pudiyono. 2012. Educational Research: Grammatical Interference towards the Students' Spoken and Written English. Jakarta:International Journal for Educational Studies.

Yusuf, Suhendra. 1994. Teori Terjemah: Pengantar ke Arah Pendekatan Linguistik dan Sosiolinguistik. Bandung: Mandar Maju. 